\title{
RYZYKO UBEZPIECZENIOWE - WSPÓŁCZESNE WYZWANIA DLA ZAKŁADÓW UBEZPIECZEŃ
}

\author{
Wanda Ronka-Chmielowiec \\ prof. dr hab., Katedra Ubezpieczeń, \\ Uniwersytet Ekonomiczny we Wrocławiu
}

\section{Wprowadzenie}

Ryzyko związane jest $\mathrm{z}$ wszelkimi formami egzystencji i działania człowieka. Ryzyko, jego istota, definicje i inne związane z nim problemy, takie jak: identyfikacja, klasyfikacja, porządkowanie, ocena i obmiar, są przedmiotem zainteresowania wielu dyscyplin naukowych, np. teorii ekonomii, finansów, ubezpieczeń, prawa, matematyki, rachunku prawdopodobieństwa i statystyki.

Ryzyko może być opisane jako zdarzenie, które może wystąpić, ale nie musi. Ryzyko jest pojęciem wieloznacznym i złożonym, stąd bardzo trudno podać jego ścisłą i uniwersalną definicję. Zatem można je definiować na różne sposoby, zależnie od aspektu, który bierze się pod uwage oraz okoliczności, jakie interesują badacza. Zależy to przede wszystkim od tego, na gruncie jakiej nauki chcemy zdefiniować ryzyko.

Ryzyko w działalności ubezpieczeniowej ma szczególne znaczenie, gdyż związane jest z celem i przede wszystkim przedmiotem tej działalności. Możemy stwierdzić, że w działalności ubezpieczeniowej występują następujące kategorie ryzyka:

- ryzyko ubezpieczeniowe - związane z przedmiotem ubezpieczenia,

- ryzyko ubezpieczyciela - związane z funkcjonowaniem zakładu ubezpieczeń,

- ryzyko ubezpieczającego - wynikające z charakteru samej umowy ubezpieczenia.

Jednak najistotniejszym jest tutaj ryzyko ubezpieczeniowe, któremu poświęcimy rozważania przedstawione w poniższym artykule. W dalszej części artykułu przedstawimy problemy związane z zarządzaniem ryzy- 
kiem ubezpieczeniowym przez zakłady ubezpieczeń. Z uwagi na fakt, że ryzyko ubezpieczeniowe charakteryzuje się dynamiką zmian w czasie wynikającą ze zmieniającego się otoczenia prawnego i ekonomicznego pochodzącego $\mathrm{z}$ różnych obszarów zmieniającego się rynku takich jak nowe technologie, nowe usługi finansowe, innowacyjność, zmiany społeczne i demograficzne oraz mieniające się przepisy prawa o charakterze regulacyjnym, to $\mathrm{w}$ artykule przedstawione zostaną dwa obszary zagadnień, które są pewnymi wyzwaniami dla zakładów ubezpieczeń. Pierwszy obszar dotyczy zmian o charakterze regulacyjno-prawnym, które zakłady ubezpieczeń muszą przestrzegać oraz drugi obszar to nowe ryzyka ubezpieczeniowe, które ubezpieczyciele muszą rozeznać i skonstruować nowe odpowiednie produkty.

\section{Zarządzanie ryzykiem ubezpieczeniowym w zakładzie ubezpieczeń}

Proces zarządzania ryzykiem ubezpieczeniowym w zakładzie ubezpieczeń obejmuje następujące etapy:

- identyfikacja i klasyfikacja ryzyka ubezpieczeniowego,

- podjęcie decyzji o ubezpieczeniu i wybór metody ubezpieczenia,

- ocena i pomiar ryzyka ubezpieczeniowego,

- kalkulacja składki ubezpieczeniowej jako podstawa finansowania ryzyka ubezpieczeniowego,

- transfer ryzyka ubezpieczeniowego poprzez stosowanie reasekuracji. Identyfikacja ryzyka ubezpieczeniowego powinna poprzedzać zawarcie kontraktu ubezpieczeniowego. Proces identyfikacji wiąże się z takimi problemami jak: wybór metodologii identyfikacji ryzyka ubezpieczeniowego oraz wybór narzędzi wykorzystywanych do identyfikacji. Jedną z podstawowych metod wykorzystywanych do identyfikacji ryzyka jest metoda oparta na analizie przeszłych szkód związanych z obserwowanym obiektem, który ma być ubezpieczony. W przypadku ubezpieczeń osobowych takich jak ubezpieczenia na życie lub ubezpieczenia chorobowe, zakłady ubezpieczeń korzystają z bazy danych i opracowań statystycznych i medycznych dotyczących występowania różnych chorób i analizy procesu umieralności badanej populacji. $\mathrm{W}$ celu identyfikacji ryzyka ubezpieczeniowego występującego w działalności gospodarczej zakłady ubezpieczeń współpracują z takimi specjalistami jak: inżynierowie różnych branż, fizycy, chemicy, finansiści, ekonomiści i prawnicy. 
Jedną z podstawowych metod wykorzystywanych do identyfikacji ryzyka jest metoda oparta na analizie przeszłych szkód związanych z obserwowanym obiektem, który ma być ubezpieczony. Metoda ta wykorzystuje przede wszystkim rachunek prawdopodobieństwa, statystykę matematyczną, a gdy uwzględnimy dynamikę zjawiska, to teorię procesów stochastycznych.

Inne narzędzia wykorzystywane w procesie identyfikacji to listy kontrolne zawierające wszystkie możliwe rodzaje ryzyka towarzyszące danej działalności, kwestionariusze analizy ryzyka, systemy ekspertowe, analiza dokumentów, wyceny nieruchomości, bazy danych dotyczące przebiegu i wysokości szkód, analiza kondycji finansowej dłużników oparta na sprawozdaniach finansowych oraz prognozy gospodarcze dotyczące konkretnej branży. W przypadku identyfikacji ryzyka, którego źródłem są żywioły przyrodnicze, trzeba skorzystać z wyników badań instytutów meteorologicznych, hydrologicznych i sejsmologicznych oraz instytutów naukowych zajmujących się badaniem zjawisk katastrof.

Drugi z problemów to klasyfikacja ryzyka. Nie ma uniwersalnych podziałów. Jeśli ustalone zostanie kryterium oraz cel podziału, to otrzyma się stosowną klasyfikację.

Jeśli przyjmiemy, że ryzyko ubezpieczeniowe związane jest z przedmiotem ubezpieczenia, to wówczas wyróżnia się ryzyko osobowe i majątkowe.

W ubezpieczeniowej teorii ryzyka wyróżnia się następujący podział na:

Ryzyko czyste, które charakteryzuje się tym, że jego realizacja przynosi tylko stratę, a brak realizacji nie przynosi ani straty, ani zysku,

Ryzyko spekulatywne, którego realizacja może mieć trzy możliwości: stratę, zysk, brak straty i zysku.

Jeśli przyjmiemy, że ryzyko ubezpieczeniowe związane jest z przedmiotem ubezpieczenia, to wyróżniamy ryzyko osobowe i majątkowe.

Ryzyko osobowe powoduje straty w dobrach osobistych, takich jak: życie, zdrowie, starzenie się i zdolność do pracy.

Ryzyko majątkowe może spowodować różne straty wynikające z posiadania nieruchomości, mienia ruchomego, prowadzenia działalności gospodarczej oraz wykonywania różnych zawodów, korzystania z różnych usług finansowych i innych.

Ze względu na praktykę ubezpieczeniową i efektywne zarządzanie ryzykiem ubezpieczeniowym duże znaczenie ma możliwość pomiaru ryzyka ubezpieczeniowego, a przede wszystkim określenie i zidentyfikowanie jego miary. Takie możliwości stwarza nowoczesna teoria ryzyka, w której to ryzyko jest modelowane.

Modele służą do zmniejszenia złożoności rozpatrywanych zjawisk w stopniu umożliwiającym ich poznanie oraz ułatwiają zrozumienie zjawisk przeszłych i umożliwiają przewidywanie zjawisk przyszłych. 
Jeśli weźmiemy pod uwagę, że ryzyko ubezpieczeniowe jest pojęciem bardzo złożonym, to podejście modelowe jest tutaj w pełni uzasadnione. Takie możliwości stwarza teoria aktuarialna, która bazuje na rachunku prawdopodobieństwa, statystyce matematycznej i teorii procesów stochastycznych.

$\mathrm{W}$ teorii aktuarialnej ryzyko jest sformalizowane i modelowane. Przyjmuje się w tej teorii, że do opisu ryzyka ubezpieczeniowego przydatna jest zmienna losowa, która przyjmuje wartości nieujemne. Uzasadnione jest to tym, że ryzyko ubezpieczeniowe ma charakter losowy, gdyż nieznane są ubezpieczycielowi i występują losowo następujące zmienne opisujące ryzyko [Ronka-Chmielowiec 1997]:

- wartości szkód,

- liczby szkód,

- momenty czasowe w których występują szkody lub straty.

Jedną z podstawowych operacji ubezpieczyciela, która generuje ryzyko zakładu ubezpieczeń jest kalkulacja składki ubezpieczeniowej. Składka ubezpieczeniowa powinna być ustalona na takim poziomie, aby zapewnić środki finansowe na wypłatę odszkodowań i świadczeń oraz tworzenie rezerw techniczno-ubezpieczeniowych i funduszy rezerwowych oraz na pokrycie kosztów działalności ubezpieczeniowej.

Podstawowym instrumentem, który poprawia wypłacalność i stosowanym przez zakłady ubezpieczeń jest reasekuracja bierna [Ronka-Chmielowiec (red.) 2004].

Zakład ubezpieczeń z uwagi na swoją działalność techniczno-ubezpieczeniową powinien zdecydować się na zastosowanie reasekuracji biernej $\mathrm{w}$ następujących sytuacjach:

- gdy suma ubezpieczenia dotycząca pojedynczego ryzyka znacznie przekracza przeciętną sumę ubezpieczenia w portfelu,

- gdy portfel ubezpieczeń charakteryzuje się dużą szkodowością mierzoną stosunkiem wypłaconych odszkodowań i świadczeń skorygowanych o rezerwy techniczno-ubezpieczeniowe do zebranej składki ubezpieczeniowej.

W praktyce ubezpieczeniowej oprócz reasekuracji tradycyjnej znajduje coraz częściej zastosowanie reasekuracja finansowa, która jest jeszcze bardziej związana z zarządzaniem ryzykiem ubezpieczyciela, gdyż nie tylko transferuje ryzyko ubezpieczeniowe, ale obejmuje swoim działaniem ryzyko finansowe takie jak:

- ryzyko czasu (timing risk) uwzględnia zmiany wartości pieniądza $\mathrm{w}$ czasie związane z przesuniętymi roszczeniami lub przedwczesną wypłatą szkód, co skutkuje obniżeniem przyszłych zysków z rezerw dla reasekuratora,

- ryzyko oceny (underwriting risk) związane z nieprzewidywalnym znacznym wzrostem szkodowości. 
Jeszcze bardziej związane $\mathrm{z}$ doskonaleniem metod zarządzania ryzykiem ubezpieczyciela są produkty typu IRM oferowane przez reasekuratorów, tzn. zintegrowane zarządzanie ryzykiem (integrated risk management) [Małek 2011]. Produkty te charakteryzują się większą elastycznością i efektywnością, gdyż lepiej wpływają na wynik operacyjny zakładu ubezpieczeń niż zawarcie osobno umowy reasekuracji klasycznej i hedgingu finansowego. Wpływają one zatem na stabilizację wartości zakładu ubezpieczeń.

Produkty IRM dotyczą ochrony całego wyniku operacyjnego i obejmują oprócz ryzyka techniczno-ubezpieczeniowego ryzyko finansowe, takie jak: ryzyko stopy procentowej, ryzyko cen akcji i ryzyko kursu walutowego. Efekty zintegrowanego zarządzania ryzykiem to:

- optymalne pokrycie szkód powstałych po stronie aktywów i pasywów zakładu ubezpieczeń, czyli pełna ochrona struktury bilansu,

- obniżenie ryzyka kapitału, co może zostać wykorzystane w dalszej działalności cedenta [Ronka-Chmielowiec 2007].

\section{Nowe regulacje prawne wynikające z Solvency II a zarządzanie ryzykiem ubezpieczeniowym w zakładzie ubezpieczeń}

Jedną z najważniejszych regulacji dla całego europejskiego rynku ubezpieczeń jest dyrektywa ramowa Solvency II. Nowe podejście do wypłacalności zakładów prowadzących działalność ubezpieczeniową lub reasekuracyjną polega na odejściu od ujmowania wypłacalności zakładów jedynie w kontekście ilościowo określonych wymogów kapitałowych. W projekcie kładzie się nacisk na powiązanie wymogów kapitałowych z rzeczywistym ryzykiem, na jakie narażone są te zakłady. Zmiany dotyczą również m.in. systemu zarządzania i procesu nadzorczego oraz określenia obowiązków informacyjnych zakładów ubezpieczeń i reasekuracji.

Obecnie zakłady ubezpieczeń w Polsce funkcjonują zgodnie z ustawą o działalności ubezpieczeniowej i reasekuracyjnej [Ustawa o działalności ubezpieczeniowej i reasekuracyjnej 2015, art. 229]. Implementacja Dyrektywy Solvency II rozpoczęła się 1 stycznia 2016 roku. Nowe podejście regulacyjne szczególnie kładzie duży nacisk na system zarządzania ryzykiem zakładu ubezpieczeń, który jest mocno związany z nowymi zasadami nadzoru dotyczącymi wypłacalności i szacowaniem stosownego kapitału, który ubezpieczyciel musi posiadać. 
System zarządzania ryzykiem obejmuje ryzyka, które należy uwzględnić w obliczeniach kapitałowego wymogu wypłacalności oraz ryzyka, które są uwzględniane jedynie częściowo lub są w tych obliczeniach pomijane.

System zarządzania ryzykiem obejmuje co najmniej:

- ocenę ryzyka przyjmowanego do ubezpieczenia i tworzenie rezerw techniczno-ubezpieczeniowych dla celów wypłacalności,

- zarządzanie aktywami i zobowiązaniami,

- lokaty, w szczególności w instrumenty pochodne,

- zarządzanie płynnością i ryzykiem koncentracji,

- zarządzanie ryzykiem operacyjnym,

- reasekurację i inne techniki przenoszenia ryzyka.

Zakład ubezpieczeń i zakład reasekuracji obliczają kapitałowy wymóg wypłacalności co najmniej raz w roku i informują organ nadzoru.

Kapitałowy wymóg wypłacalności pokrywa co najmniej następujące ryzyka:

- aktuarialne $\mathrm{w}$ pozostałych ubezpieczeniach osobowych oraz ubezpieczeniach majątkowych,

- aktuarialne w ubezpieczeniach na życie,

- aktuarialne w ubezpieczeniach zdrowotnych,

- rynkowe,

- kredytowe,

- operacyjne.

Stosowane mogą być dwa modele obliczania kapitałowego wymogu wypłacalności: standardowy i wewnętrzny.

Kapitałowy wymóg wypłacalności obliczany według formuły standardowej stanowi sumę:

- podstawowego kapitałowego wymogu wypłacalności,

- wymogu kapitałowego dla ryzyka operacyjnego,

- dostosowania z tytułu zdolności rezerw techniczno-ubezpieczeniowych dla celów wypłacalności i odroczonego podatku dochodowego do pokrycia strat.

Podstawowy kapitałowy wymóg wypłacalności składa się co najmniej z następujących modułów ryzyka:

- aktuarialnego w pozostałych ubezpieczeniach osobowych oraz ubezpieczeniach majątkowych,

- aktuarialnego w ubezpieczeniach na życie,

- aktuarialnego w ubezpieczeniach zdrowotnych,

- rynkowego,

- niewykonywania zobowiązania przez kontrahenta [Ustawa o działalności ubezpieczeniowej i reasekuracyjnej 2015].

Jak widać trzy pierwsze moduły ryzyka dotyczą ryzyka ubezpieczeniowego, co wiąże się z doskonaleniem zarządzania ryzykiem ubezpieczeniowym. 
Zakład ubezpieczeń i zakład reasekuracji mogą obliczać kapitałowy wymóg wypłacalności przy zastosowaniu pełnego albo częściowego modelu wewnętrznego zatwierdzonego w drodze decyzji przez organ nadzoru. W przypadku stosowania modelu wewnętrznego jeszcze większej wagi nabiera zarządzanie ryzykiem ubezpieczeniowym.

Minimalny wymóg kapitałowy zakładu ubezpieczeń i zakładu reasekuracji jest wyznaczany jako funkcja liniowa zbioru lub podzbioru następujących zmiennych:

- rezerw techniczno-ubezpieczeniowych dla celów wypłacalności,

- składki przypisanej,

- sumy na ryzyku,

- odroczonego podatku dochodowego,

- kosztów administracyjnych [Ustawa o działalności...].

W ramach zarząazania ryzykiem zakłady ubezpieczeń powinny stosować instrumenty ostrożnościowe, które można przyporząakować poszczególnym modułom ryzyka towarzyszącym tej działalności.

Obecnie przedstawimy wybrane instrumenty ostrożnościowe, które mogą być stosowane w obszarze ryzyka ubezpieczeniowego. Podstawowy cel stosowania tych instrumentów to dywersyfikacja i redukcja koncentracji [Czerwińska 2016].

\begin{tabular}{|l|}
\hline Współczynniki dywersyfikacji geograficznej ryzyka składki i rezerw \\
\hline Segmentacja geograficzna oraz czynniki ryzyka dla podmodułów \\
\hline Macierze zależności dla ryzyka składki i rezerw \\
\hline $\begin{array}{l}\text { Parametry podmodułów i współczynniki zależności dla regionów w odniesieniu do konkret- } \\
\text { nych rodzajów ryzyka: huraganu, trzęsienia ziemi, powodzi i gradobicia }\end{array}$ \\
\hline Wagi ryzyka dla stref ryzyka katastroficznego \\
\hline $\begin{array}{l}\text { Grupy ryzyka odpowiedzialności cywilnej, czynniki ryzyka oraz współczynniki zależności dla } \\
\text { podmodułu ryzyka odpowiedzialności cywilnej }\end{array}$ \\
\hline $\begin{array}{l}\text { Segmentacja zobowiązań ubezpieczeniowych i reasekuracyjnych oraz odchylenia standardo- } \\
\text { we podmodułu ryzyka składki i rezerw }\end{array}$ \\
\hline Metoda ryzyka składki \\
\hline Metody ryzyka rezerw \\
\hline $\begin{array}{l}\text { Ustalenie wartości rezerw techniczno-ubezpieczeniowych jako sumy najlepszego oszacowa- } \\
\text { nia i marginesu ryzyka }\end{array}$ \\
\hline $\begin{array}{l}\text { Najlepsze oszacowanie odpowiada ważonej prawdopobodobieństwem średniej przyszłych } \\
\text { przepływów pieniężnych przy uwzględnieniu wartości pieniądza w czasie (oczekiwanej } \\
\text { obecnej wartości przyszłych przepływów pieniężnych) przy zastosowaniu odpowiedniej } \\
\text { struktury terminowej stopy procentowej wolnej od ryzyka }\end{array}$ \\
\hline Margines ryzyka
\end{tabular}

Tabela 1. Wybrane instrumenty ostrożnościowe dla ryzyka ubezpieczeniowego Źródło: Czerwińska [2016]. 


\section{Ryzyko ubezpieczeniowe o charakterze osobowym - nowe wyzwania}

Ryzyko osobowe może wygenerować straty lub zwiększone potrzeby finansowe pochodzące $\mathrm{z}$ takich zdarzeń jak: śmierć człowieka, choroby, następstwa nieszczęśliwych wypadków, inwalidztwo, niezdolność do pracy, utrata pracy, starzenie się, opieka nad dziećmi, opieka nad osobami starszymi i inne.

Ryzyko osobowe może być objęte następującymi ubezpieczeniami: na życie, w tym na wypadek śmierci i dożycie, następstw nieszczęśliwych wypadków, zdrowotne, rentowe, od utraty pracy, od bezrobocia, posagowe, opiekuńcze, o charakterze oszczędnościowym jako uzupełniające w systemie emerytalnym, odpowiedzialności cywilnej za szkody na osobie. Część z tych ubezpieczeń mieści się w obszarze ubezpieczeń społecznych wynikających z polityki społecznej państwa. Jednak ubezpieczenia społeczne często nie gwarantują pełności ochrony ubezpieczeniowej oraz nie obejmują wielu ryzyk osobowych, stąd znajdują tutaj zastosowanie ubezpieczenia gospodarcze, które uzupełniają świadczenia społeczne. Ponadto niektóre ryzyka osobowe mogą być rekompensowane w wyniku realizacji tylko z ubezpieczeń gospodarczych dobrowolnych.

Podstawowym źródłem ryzyka osobowego są procesy demograficzne, które charakteryzują się zmiennością i generują nowe zjawiska, które wymuszają na zakładach ubezpieczeń nowe inne podejście w konstrukcji produktów ubezpieczeniowych klasycznych, jak również nowych ofert. Inne źródła to zmiany obyczajowe o charakterze społecznym i kulturowym oraz zwiększająca się świadomość ubezpieczeniowa i niewystarczające świadczenia pochodzące $\mathrm{z}$ ustawowego systemu emerytalnego. Dodatkowo w związku z rozwojem bancassurance w obszarze usług kredytowych pojawia się zapotrzebowanie na usługi ubezpieczeniowe osobowe powiązane z kredytami.

Rozrodczość i umieralność poddane są pewnym prawom natury. Ingerencja człowieka - poprzez rozwój medycyny, przedsięwzięcia sanitarne, poprawę warunków bytu - spowodowała tendencję spadkową umieralności. Ponadto długość życia ludzkiego zależy również od pewnych czynników losowych, takich jak: warunki klimatyczne, uwarunkowania kulturowe, tryb życia, sposób odżywiania i inne. Przyjmuje się zatem, że dobrym modelem opisującym czas życia ludzkiego jest pewna ciągła zmienna losowa.

W tabeli 2 przedstawimy jak zmieniał się w Polsce średni czas życia kobiet i mężczyzn. Jak widać proces ten jest dynamiczny i w związku z powyższym zwiększająca się długość życia kobiet i mężczyzn stawia nowe 
wyzwania przed instytucją ubezpieczeniową $\mathrm{w}$ zakresie zmian w produktach typu ubezpieczenia na życie i dożycie oraz w ubezpieczeniach zdrowotnych, opiekuńczych i uzupełniających o charakterze emerytalnym (długoterminowych oszczędnościach).

\begin{tabular}{|l|c|c|c|c|c|}
\hline \multicolumn{1}{|c|}{ Rok } & 1955 & 1970 & 1985 & 2000 & 2015 \\
\hline Kobiety & 66,2 & 73,3 & 74,8 & 78 & 81,6 \\
\hline Mężczyźni & 68 & 66,6 & 66,5 & 69,7 & 73,6 \\
\hline
\end{tabular}

Tabela 2. Średnie trwanie życia kobiet i mężczyzn w Polsce (w latach) Źródło: GUS (stat.gov.pl., dostęp: 22.08.2016).

Innym obszarem, w którym pojawiły się nowe ryzyka ubezpieczeniowe są ubezpieczenia odpowiedzialności cywilnej za szkody na osobie. Przyczyniło do tego się przede wszystkim zwiększenie się świadomości społecznej, ale także pośrednio podwyższenie się standardów życia oraz poziomu wykształcenia społeczeństwa.

Tabela 3 pokazuje jak wzrósł udział ubezpieczeń osobowych w porównaniu z majątkowymi we współpracy bankowo-ubezpieczeniowej, co jest też pewnym nowym zjawiskiem dla zakładów ubezpieczeń.

\begin{tabular}{|l|r|r|r|r|r|r|r|}
\hline \multicolumn{1}{|c|}{ Rok } & \multicolumn{1}{c|}{2015} & 2014 & 2013 & 2012 & 2011 & 2010 & 2009 \\
\hline Dział I & $39,2 \%$ & $40,8 \%$ & $46,7 \%$ & $53,5 \%$ & $51,6 \%$ & $51,7 \%$ & $50,4 \%$ \\
\hline Dział II & $9,7 \%$ & $10,4 \%$ & $9,2 \%$ & $7,2 \%$ & $8,8 \%$ & $9,1 \%$ & $8,5 \%$ \\
\hline
\end{tabular}

Tabela 3. Udział bancassurance w sprzedaży ubezpieczeń Źródło: piu.org.pl (dostęp: 20.08.2016).

\begin{tabular}{|l|r|r|r|r|r|r|r|r|r|r|r|r|}
\hline Rok & 2005 & 2006 & 2007 & 2008 & 2009 & 2010 & 2011 & 2012 & 2013 & 2014 & 2015 \\
\hline \multicolumn{10}{|c|}{ Struktura składki przypisanej brutto wg grup w Dziale I (w \%) } \\
\hline Gr. 1 & 45,0 & 38,4 & 38,6 & 72,8 & 63,5 & 59,7 & 52,8 & 53,3 & 53,3 & 38,4 & 38,6 \\
\hline Gr. 2 & 1,0 & 0,7 & 0,5 & 0,3 & 0,4 & 0,4 & 0,4 & 0,3 & 0,3 & 0,7 & 0,5 \\
\hline Gr. 3 & 36,6 & 46,0 & 46,9 & 16,1 & 21,3 & 25,8 & 32,4 & 33,1 & 33,1 & 46,0 & 46,9 \\
\hline Gr. 4 & 0,2 & 0,2 & 0,2 & 0,2 & 0,2 & 0,3 & 0,3 & 0,3 & 0,3 & 0,2 & 0,2 \\
\hline Gr. 5 & 16,4 & 14,4 & 13,6 & 10,5 & 14,4 & 13,6 & 14,0 & 12,9 & 12,9 & 14,4 & 13,6 \\
\hline
\end{tabular}

Tabela 4. Zmiany w strukturze ubezpieczeń na życie w Polsce w latach 2005-2015 Źródło: piu.org.pl (dostęp: 23.08.2016). 
Tabela 4 ilustruje jak w ostatnich latach zmieniała się struktura sprzedaży grup ubezpieczeń na życie. Widać wyraźnie, że wzrosło zainteresowanie Polaków ubezpieczeniami o charakterze inwestycyjnym, które są długoterminowe i pełnią rolę bardziej oszczędnościową niż ochronną. Wynika to $z$ większej zamożności społeczeństwa i potrzeby uzupełnienia zabezpieczeń emerytalnych. Tutaj wyróżnia się grupa 3, czyli ubezpieczenia na życie i dożycie $z$ ubezpieczeniowym funduszem kapitałowym. Ubezpieczenia te proponowane przez wiele zakładów ubezpieczeń na życie są trudne dla zakładów ubezpieczeń i wywołują wiele kontrowersji wśród klientów. Pojawiły się skargi sądowe i do Rzecznika Finansowego na sposób funkcjonowania tych produktów, dotyczące sposobu naliczania prowizji i opłaty likwidacyjnej. Z pewnością w przyszłości zakłady ubezpieczeń będą zmuszone do doskonalenia tych produktów.

\section{Ryzyko ubezpieczeniowe o charakterze majątkowym - nowe wyzwania}

Ryzyko majątkowe objęte ubezpieczeniami z Działu II jest bardzo zróżnicowane i pochodzi z różnych obszarów działalności człowieka. Tabela 5 ilustruje jak w ostatnich latach kształtowała się struktura sprzedaży w Dziale II, jakie pojawiły się tendencje i zagrożenia.

\begin{tabular}{|l|r|r|r|r|r|r|r|r|r|r|r|r|r|}
\hline \multicolumn{1}{|c|}{ Rok } & 2005 & 2006 & 2007 & 2008 & 2009 & 2010 & 2011 & 2012 & 2013 & 2014 & 2015 \\
\hline \multicolumn{9}{|c|}{ Struktura składki przypisanej brutto wg rodzajów działalności w Dziale II (w \%) } \\
\hline Gr. 1 i 2 & 5,7 & 6,0 & 6,0 & 7,5 & 7,1 & 7,1 & 6,6 & 6,8 & 6,8 & 5,7 & 6,0 \\
\hline Gr. 8 i 9 & 17,8 & 17,7 & 17,7 & 16,3 & 17,8 & 18,3 & 19,1 & 19,6 & 19,6 & 17,8 & 17,7 \\
\hline Gr. 3 & 27,8 & 25,7 & 25,7 & 25,5 & 23,1 & 23,1 & 22,8 & 21,4 & 21,4 & 27,8 & 25,7 \\
\hline Gr. 10 & 34,9 & 34,7 & 34,7 & 34,4 & 33,5 & 33,1 & 34,0 & 34,0 & 34,0 & 34,9 & 34,7 \\
\hline Gr. 4-8, 11 i 12 & 1,9 & 1,8 & 1,8 & 1,5 & 1,4 & 1,2 & 1,2 & 1,3 & 1,3 & 1,9 & 1,8 \\
\hline Gr. 13 & 4,5 & 5,0 & 5,0 & 4,8 & 5,3 & 5,5 & 5,7 & 6,7 & 6,7 & 4,5 & 5,0 \\
\hline Gr. 14-17 & 4,5 & 5,5 & 5,5 & 6,6 & 8,1 & 8,1 & 7,1 & 6,1 & 6,1 & 4,5 & 5,5 \\
\hline Gr. 18 & 0,6 & 1,1 & 0,8 & 0,9 & 1,4 & 1,5 & 1,6 & 1,7 & 1,7 & 0,6 & 1,1 \\
\hline $\begin{array}{l}\text { Reasekuracja } \\
\text { Czynna }\end{array}$ & 2,3 & 2,5 & 2,8 & 2,5 & 2,3 & 2,2 & 1,9 & 2,3 & 2,3 & 2,3 & 2,5 \\
\hline
\end{tabular}

Tabela 5. Zmiany w strukturze ubezpieczeń w Polsce w latach 2005-2015 w Dziale II Źródło: piu.org.pl (dostęp: 23.08.2016). 
W Dziale II struktura portfela była w okresie lat 2005-2015 bardzo stabilna, gdyż trudno zauważyć jakieś znaczące zmiany w udziałach poszczególnych grup produktów. Największe udziały, które łącznie dają ponad $50 \% \mathrm{w}$ portfelu to grupy 3 i 10, czyli ubezpieczenia komunikacyjne, casco oraz odpowiedzialności cywilnej. W grupie 13, czyli w ubezpieczeniach odpowiedzialności cywilnej nastąpił wzrost w latach 2012 i 2013, ale potem udział ich spadł, choć w roku 2015 w porównaniu z 2014 znowu wzrósł, co może wykazywać pewną tendencję wzrostową. Ubezpieczenia finansowe reprezentowane przez grupy 14-17 wykazywały wzrost udziału w latach 2009-2011.

Jednak z uwagi na duży rozwój nowych technologii i częściej występujące zjawiska o charakterze katastroficznym przed zakładami ubezpieczeń pojawiają się nowe wyzwania i nowe podejścia do postępowania z ryzykiem ubezpieczeniowym o charakterze majątkowym. Można tutaj wyodrębnić najważniejsze obszary z nimi związane. Są to:

1. Istnienie i funkcjonowanie cyberprzestrzeni;

2. Ataki terrorystyczne;

3. Zwiększenie świadomości społecznej i wyższe standardy życia.

Do głównych zagrożeń związanych z istnieniem cyberprzestrzeni możemy zaliczyć [Grabowska 2015: 112]:

- wyciek danych osobowych lub handlowych,

- zniszczenie danych lub informacji,

- utratę zysku wskutek ataku informatycznego,

- ponoszenie dodatkowych kosztów związanych z odpowiedzią na ataki komputerowe,

- utratę lub naruszenie reputacji,

- cyberwymuszenia,

- cyberterroryzm.

W związku z dość dużym zakresem ewentualnych szkód i rosnącym zainteresowaniem ze strony klientów możliwością ubezpieczenia się od skutków ich występowania pojawiło się pojęcie cyberubezpieczeń.

Inny obszar, który szczególnie dotyka ryzyka majątkowe objęte ubezpieczeniami Działu II to różnego rodzaju katastrofy.

Mówimy, że ryzyko ma cechy katastrofalne jeśli jego realizacja generuje wielkie szkody losowe, które mogą wystąpić:

- w jednym obiekcie,

- w wielu obiektach,

a które mogą być kumulacją bardzo dużej liczby nawet drobnych szkód powstałych w wyniku katastrofy naturalnej lub spowodowanej przez człowieka. 
Ryzyko katastrofalne charakteryzuje się następującymi własnościami:

- nie spełniony jest warunek o niezależności występowania szkód,

- prawdopodobieństwo realizacji ryzyka katastrofalnego jest bardzo małe i trudne do oszacowania,

- nie zachodzi warunek powtarzalności jednorodnych szkód, który pozwala korzystać z prawa wielkich liczb, a który jest jedną z cech ubezpieczalności ryzyka,

- szkody powstałe w wyniku realizacji ryzyka katastrofalnego pojawiają się prawie w tym samym czasie.

Stąd jeśli szkody wygenerowane przez ryzyko katastrofalne są ubezpieczone, to realizacja tego ryzyka implikuje konieczność zagwarantowania rekompensaty wielu ubezpieczonym jednocześnie prowadząc do nadzwyczajnych wymagań finansowych w stosunku do nadwyżek zakładu ubezpieczeń, a w przypadku bardzo dużych katastrof odnosi się to do całego sektora ubezpieczeniowego, nawet w skali międzynarodowej. Dla ryzyka katastrofalnego stosowana jest powszechnie reasekuracja.

W przypadku ryzyka katastrofalnego pojawiają się następujące trudności związane z jego oceną i pomiarem:

- nieporównywalność danych opisujących zdarzenia katastrofalne z powodu zmieniającego otoczenia, zmieniającej się wartości ubezpieczonego majątku, przyrostu lub spadku populacji ludzi zamieszkujących zagrożony teren, zmian klimatycznych, zmieniającej się technologii, występującej inflacji i innych,

- mała liczba danych o zdarzeniach katastrofalnych, które występują rzadko i stąd zbyt krótkie historyczne szeregi czasowe, które nie mogą dać pełnej informacji o danym zjawisku katastrofalnym.

W związku z powyższym wskazane jest:

- wykorzystywanie danych z innych dziedzin, szczególnie danych sejsmicznych, meteorologicznych, ekonomicznych i innych do modelowania zdarzeń katastrofalnych,

- wykorzystanie metod symulacyjnych do oceny rozkładów prawdopodobieństw i ich parametrów zmiennych losowych opisujących zdarzenia katastrofalne [Ronka-Chmielowiec 2006].

\section{Podsumowanie}

Jak widać z powyższych rozważań zarządzanie ryzykiem ubezpieczeniowym charakteryzuje się dużą dynamiką zmian wynikających z nowych regulacji prawnych, które mają zabezpieczyć doskonalsze za- 
rządzanie ryzykiem zakładu ubezpieczeń szczególnie w obszarze bezpieczeństwa finansowego ubezpieczyciela i klientów korzystających z usług ubezpieczeniowych. Na współcześnie funkcjonujących rynkach finansowych są to zadania ciągle aktualne i priorytetowe. Jednocześnie dla zakładów ubezpieczeń istotne jest również doskonalenie metod postępowania z ryzykiem ubezpieczeniowym, zwłaszcza z nowymi rodzajami ryzyka, które mogą być objęte ochroną ubezpieczeniową, a które pojawiają się wyniku rozwoju cywilizacyjnego, nowych rozwiązań technologicznych, zmianami kulturowymi, rozwojem medycyny, zwiększoną świadomością i wiedzą współczesnych ludzi. Artykuł jest pewnym wprowadzeniem do dalszych badań, które są to zagadnienia ważne i przyszłościowe.

\section{Bibliografia}

Czerwińska T. (2016), Regulacje mikroostrożnościowe sektora ubezpieczeniowego, [w:] T. Czerwińska, K. Jajuga (red.), Ryzyko instytucji finansowych. Współczesne trendy i wyzwania, Wydawnictwo C.H.Beck, Warszawa.

Grabowska T. (2015), Cyberprzestępczość w dziedzinie finansów - ryzyka cybernetyczne, „Rozprawy Ubezpieczeniowe”, z. 18 (1).

Małek A. (2011), Reasekuracja, Klasyczne i alternatywne metody transferu ryzyka ubezpieczeniowego, Poltext, Warszawa.

Ronka-Chmielowiec W. (1997), Ryzyko w ubezpieczeniach - metody oceny, Wydawnictwo AE Wrocław.

Ronka-Chmielowiec W. (red.) (2004), Zarządzanie finansami w zakładach ubezpieczeń, Oficyna Wydawnicza Branta, Bydgoszcz-Warszawa-Wrocław.

Ronka-Chmielowiec W. (2007), Zarządzanie ryzykiem w zakładzie ubezpieczeń, [w:] K. Jajuga (red.), Zarządzanie ryzykiem, Wydawnictwo PWN, Warszawa.

Ustawa o działalności ubezpieczeniowej i reasekuracyjnej z dnia 25 października 2015 r. (Dz.U. z dnia 10 listopada 2015 r., poz. 1844).

\section{RYZYKO UBEZPIECZENIOWE - WSPÓŁCZESNE WYZWANIA DLA ZAKŁADÓW UBEZPIECZEŃ}

Ryzyko w działalności ubezpieczeniowej ma szczególne znaczenie, gdyż związane jest z celem i przede wszystkim przedmiotem tej działalności.

Najistotniejszym jest ryzyko ubezpieczeniowe, któremu poświęcono rozważania przedstawione w artykule. Przedstawione zostały problemy związane z zarzą- 
dzaniem ryzykiem ubezpieczeniowym przez zakłady ubezpieczeń. Z uwagi na fakt, że ryzyko ubezpieczeniowe charakteryzuje się dynamiką zmian wynikającą ze zmieniającego się otoczenia prawnego i ekonomicznego pochodzącego z różnych obszarów zmieniającego się rynku takich jak nowe technologie, nowe usługi finansowe, innowacyjność, zmiany społeczne i demograficzne oraz zmieniające się przepisy prawa o charakterze regulacyjnym, to w artykule zaprezentowane zostały dwa obszary zagadnień, które są pewnymi wyzwaniami dla zakładów ubezpieczeń. Pierwszy obszar dotyczy zmian o charakterze regulacyjno-prawnym, aktualnie związanych z implementacją Solvency II, które zakłady ubezpieczeń muszą przestrzegać oraz drugi obszar to nowe ryzyka ubezpieczeniowe, które ubezpieczyciele muszą rozeznać i skonstruować nowe odpowiednie produkty. W drugim obszarze oddzielnie zostały scharakteryzowane nowe wyzwania i problemy dla ryzyka ubezpieczeniowego osobowego i majątkowego, ponieważ każda z tych kategorii ryzyka ma inną specyfikę.

Słowa kluczowe: ryzyko ubezpieczeniowe, ryzyko osobowe, ryzyko majątkowe, zarządzanie ryzykiem, reasekuracja, ryzyko aktuarialne, ubezpieczenia na życie, ubezpieczenia zdrowotne.

\section{INSURANCE RISKS - PRESENT-DAY CHALLENGES IN INSURANCE INDUSTRY}

Risk in the Insurance Business is of paramount importance since it is directly related to the aim, and first of all to the subject of the business activity in question. The most important, however, is the insurance risk which is dealt with in the present paper. We present the problems connected with the insurance risk management implemented by insurance companies. Given the fact that insurance risk is characterized by change dynamics resulting from the forever changing legal and economic environment, whose changes come from various areas of the market which never remains the same due to still newer technologies, novel financial services, innovativeness, social and demographic changes and legal regulations in business being changed almost on a daily basis, in the present paper we discuss two sets of issues which pose certain challenges to insurance companies. The first one concerns changes which are of legal and regulatory character currently binding and connected with the implementation of Solvency II which insurers must observe, and the second area which deals with new insurance risks which must be recognized by the insurers and relevant new products must be constructed. In this second area, new challenges and problems vis-à-vis personal and property insurance risk are described separately, for each of these risk categories has its own peculiar character.

Keywords: insurance risk, personal risk, property risk, risk management, reassurance, aktuarial risk, life insurance, health insurance. 